\begin{tabular}{|c|c|c|c|c|c|c|}
\hline \multirow{4}{*}{ Impact Factor: } & ISRA (India) & $=3.117$ & SIS (USA) & $=0.912$ & ICV (Poland) & $=6.630$ \\
\hline & ISI (Dubai, UAE & $=\mathbf{0 . 8 2 9}$ & РИНЦ (Russia & $=0.156$ & PIF (India) & $=1.940$ \\
\hline & GIF (Australia) & $=0.564$ & ESJI (KZ) & $=\mathbf{5 . 0 1 5}$ & IBI (India) & $=4.260$ \\
\hline & JIF & $=1.500$ & SJIF (Morocco & $=5.667$ & OAJI (USA) & $=0.350$ \\
\hline
\end{tabular}

SOI: $\underline{1.1 / \mathrm{TAS}} \quad$ DOI: $\underline{10.15863 / \mathrm{TAS}}$
International Scientific Journal
Theoretical \& Applied Science
$\begin{array}{ll}\text { p-ISSN: } 2308-4944 \text { (print) } \quad \text { e-ISSN: } 2409-0085 \text { (online) } \\ \text { Year: } 2019 \quad \text { Issue: } 01 \quad \text { Volume: } 69 \\ \text { Published: } 30.01 .2019 \quad \underline{\text { http://T-Science.org }}\end{array}$

SECTION 31. Economic research, finance, innovation, risk management.
QR - Issue

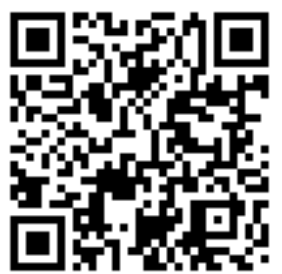

QR - Article

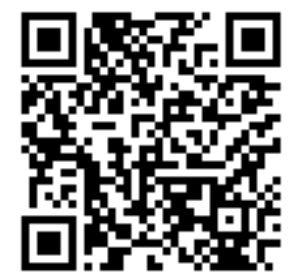

Abdimannon Buharovich Khayitov

Candidate of Economic Sciences, Associate Professor, Tashkent state university of economics, Tashkent city, Uzbekistan

Dilshod Ravshanovich Babayev assistant at Tashkent state university of economics, Tashkent city, Uzbekistan

\title{
INNOVATIVE ACTIVITY AND LABOR ORGANIZING IN FAMILY BUSINESS
}

Abstract: This article discusses the role and types of family business in today's world, its relevance, theoretical basis and the effective utilization of its potential. Also, issues of the use of economic resources for the development of family entrepreneurship, introduction of innovative processes in their activity were studied. As an example, the analysis of the current state of small business and entrepreneurship in the Namangan region of the Republic has been analyzed. Effective labor organizing of family businesses is highlighted.

Key words: business, household, family business, innovation, management, small business, labor.

Language: English

Citation: Khayitov, A. B., \& Babayev, D. R. (2019). Innovative activity and labor organizing in family business. ISJ Theoretical \& Applied Science, 01 (69), 321-325.

Soi: http://s-o-i.org/1.1/TAS-01-69-45 Doi: crossef https://dx.doi.org/10.15863/TAS.2019.01.69.45

\section{Introduction}

The economy of our country is growing from year to year. Together with the development of various sectors of the economy, different regions of our country are also improving and changing their landscapes. The influence of these territories on the economy of our country is growing.

Gross Domestic Product of Uzbekistan grew by $8.1 \%$, industrial production by $8.3 \%$, agriculture by $6.9 \%$, capital construction by $10.9 \%$ and retail trade by $14.3 \%$. Approximately 70 percent of the products produced were finished goods with high added value.

As a result of the measures taken in Namangan to support small business and entrepreneurship, the small business entities in the economy are increasing year by year. By the end of 2014, the share of small businesses in gross regional product amounted to $79.7 \%$, in 2015 it reached $80.2 \%$. This figure was 79.5 percent by the end of 2013 . As of January 1 , $2015,15,122$ small businesses were registered in the region, which rose $104.7 \%$ year-on-year in January 2014.

In particular, while analyzing the share of small business in the sectors of the economy, the share of the industry in the industrial output in 2013 amounted to $48.8 \%$, while in 2014 this figure increased by 0.7 points to $49.5 \%$.

When analyzing the share of small business in the sectors of the economy, the share of agriculture in the industry was $99.1 \%(+0.1$ points more than in the corresponding period of the previous year), construction works $-87.9 \%(+0.1)$, retail trade $45.7 \% 0.9)$ and $63.2 \%(+0.8)$ in the total service.

By the end of 2015 , the volume of exported products increased by $115.6 \%$ year-on-year to $\$ 56.1$ million. As a result, the share of small businesses in the region's exports increased from $48.1 \%$ to $60.3 \%$, respectively.

At the same time, along with all the branches and sectors of the national economy, the family business has made a significant contribution to the country's development in recent years. Family entrepreneurship has also contributed significantly to the domestic market of employment, as well as to the growth of domestic commodity markets, as well as the employment of the country's population.

Approaches to the content of household and family business

So far, economic literature has formed a number of attitudes towards the evolution of family 


\begin{tabular}{|c|c|c|c|c|c|c|}
\hline \multirow{4}{*}{ Impact Factor: } & ISRA (India) & $=3.117$ & SIS (USA) & $=0.912$ & ICV (Poland) & $=6.630$ \\
\hline & ISI (Dubai, UAE & $=0.829$ & РИНЦ (Russia & $=0.156$ & PIF (India) & $=1.940$ \\
\hline & GIF (Australia) & $=0.564$ & ESJI (KZ) & $=\mathbf{5 . 0 1 5}$ & IBI (India) & $=4.260$ \\
\hline & JIF & $=1.500$ & SJIF (Morocco & $=5.667$ & OAJI (USA) & $=0.350$ \\
\hline
\end{tabular}

businesses, the family, its social function, the content of family businesses, the peculiarities of its implementation, and the role of family entrepreneurship in the economy.

Many economists studied problems of entrepreneurship, small business, organizing and management of enterprises as well as Khodiev B.Yu [2], Hizrich. R. Piters. M.[3], ], Gulomov.S.S. [4], Abdullaev Yo, Karimov F. [5], Berkinov B.B., Akhmedov U.Q. [6], Tursunov B.O. [7-8], Kachaner, Stalk, Bloch [9], Carlock, Randel S [10], Shodieva G.M. [11] and others. In some publications, the family has been viewed as a business entity and has the concept of "family business". In particular, "family businesses - family, family, and family, to each other for the purpose of producing, doing business and having their own property in order to meet social, economic and spiritual needs and to earn a certain amount of income, a group of people living together to raise children and reproductive health "(G.Shodieva, 2008). In other literature, the notion of "family" can be derived from a single individual living independently of the family, or a few people who are related or not linked to a kinship relationship. One can be a household, amoo family and households may have a large number of people, but they are not always in touch with relatives. Organizational legal form of family business, as a legal entity, is a family-owned enterprise. In the absence of a legal entity, family business is envisaged by other legislative acts.

The Law of the Republic of Uzbekistan "On Family Entrepreneurship" establishes the activities of the family business enterprise, which places the heads of the able-bodied family, their spouse, children and grandchildren, the parents, children and grandchildren of these enterprises, as well as step-bystep brothers and sisters, their husbands and their children, their uncles and their uncles and grandchildren, and may be employed by hired laborers.

The Family Entrepreneurship Act specifies the family business as described below:

"Family entrepreneurship is an initiative that is run by family members in order to earn income (profit) under their own responsibility.

Family business is based on the volunteerism of its participants." [1]

The family and family business are paying particular attention to the leadership of our country. "It is of particular importance to further strengthen the institution of the family and upgrade our work to a qualitatively new level, while living today with the goal of creating a free democratic state, a free and prosperous life for our people," said President Karimov at the solemn ceremony dedicated to the 23rd anniversary of the Constitution of the Republic of Uzbekistan.

\section{business}

Effective use of economic resources in family

When creating a future perspective of family businesses, it is necessary to be especially careful about the use of economic resources. Among the economic resources, financial resources, along with technological, material and labor resources, play an important role. In the absence of financial resources, the majority of family businesses attract investment. When attracting investments, it is important to make effective use of each sum or unit. Today, the vast majority of households have the benefit of investing. That is why it is necessary to improve the investment activity of family businesses. Investing activities in this area at present do not meet the changing demands of the time and the conditions of the global financial and economic crisis. The global financial and economic crisis requires further activation of economic entities. In particular, it is necessary to further improve the operational management of the family business entities and their investment activities. To do this, it is necessary to increase the amount of investment attracted to family businesses.

Taking into account the terms of investment financing, it is necessary to conduct research to increase the volume of investments in the regions of the country and in the family enterprises. These studies include the following::

- Establishment and implementation of a program for their reproduction, taking into account the resources and timing of the main production funds;

- selection of an optimal mechanism for regulating the investment process;

- identifying their own resources and balancing the sources of capital investment financing;

- connect with foreign partners and attract their funds to the regional economy;

- increasing the efficiency of capital investment.

Investment financing will largely depend on the country's economic policies, legislation (primarily tax laws), the investment attractiveness infrastructure, the country's economic situation, and others.

Another issue for family businesses is the creation of effective utilization of investments. An important aspect of investing is the design and production. This means that for a certain period of time, the priority of the distribution of investments at the disposal of the whole society is their competitiveness.

In order to improve the investment activity of the region's family businesses, it is necessary to expand their foreign economic relations and attract foreign investment. Regional interests of potential investors should be taken into account in this respect.

It is necessary to create free economic zones to attract more investment. Free economic zone is a special area within the country, with the active 


\begin{tabular}{|c|c|c|c|c|c|c|}
\hline \multirow{4}{*}{ Impact Factor: } & ISRA (India) & $=3.117$ & SIS (USA) & $=0.912$ & ICV (Poland) & $=6.630$ \\
\hline & ISI (Dubai, UAE & $=0.829$ & РИНЦ (Russia) & $=0.156$ & PIF (India) & $=1.940$ \\
\hline & GIF (Australia) & $=0.564$ & ESJI (KZ) & $=5.015$ & IBI (India) & $=4.260$ \\
\hline & JIF & $=1.500$ & SJIF (Morocco) & $=5.667$ & OAJI (USA) & $=0.350$ \\
\hline
\end{tabular}

involvement of foreign capital, all necessary conditions for the creation of highly effective, export-oriented goods and services.

Tax breaks in the current distribution of free economic zones in the global economy cannot be a major incentive for current investment flows to the region. Today, factors such as political stability, investment guarantees, infrastructure quality, workforce qualification, simplification of administrative procedures, as well as opportunities to get relatively inexpensive loans in the domestic market are important. At the same time, all of these priorities will be "launched" only if they are combined with the basic pre-determinant characteristics of the region.

The experience of the free zone and the interregional competition for attracting foreign investment will lead to the unification of investors, and on this basis, investors will be invited to the region. Such works are being carried out at the airport in Navoi.

In order to achieve economic growth, not only increase the volume of investment but also determine the direction and composition of the economy. For investment, it is necessary to choose such types of production and enterprises that they can quickly cover themselves and give them a high level of economic and technological benefits. In this case, investment returns and their effectiveness are crucial. This will give an impetus for the revitalization of the investment process and, in the future, will allow choosing the preferred sectors and managing subjects for investment. Investment short-term policy should be based on long-term strategy, taking into account the importance of sectors and businesses that provide economic growth.

\section{business \\ Efficiency of innovative activity in family}

We contribute to the further development of the domestic economy through the improvement of investment activity in the family businesses, we will further deepen the processing of raw resources, increase export volumes of ready products instead of exporting raw materials to foreign countries, and meet the needs of the country's population.

One of the major goals of the country in the process of liberalization of the economy and further deepening of economic reforms is the creation of a greater system of opportunities for the development of private family business in the non-governmental sector of the economy. It is important to increase investment attraction in this area and, most importantly, to transform family businesses into leading industries, which provide employment for the population of the republic, provide employment, export-oriented goods, and currency gains for our economy.
Innovation should be the core of family business. To gain a reputable name, any person must work on himself, seek out, create, and search for new ones. A family entrepreneur, who struggles to survive the challenge of a competitive market economy, must be innovative and innovative. This is a vital necessity. Innovation is a law of competition, a unique feature of a market economy, a market less system never develops.

No family businessman has the same potential. In determining their innovative potential, one should pay particular attention to:

1. Rewards. It encourages a family entrepreneur to risk innovation.

2. Capacity. Opportunity for Innovative Business Innovation.

3. Restrictions. Restricts and limits the innovative entrepreneurial activity.

The family businessman is constantly searching for his own benefit. To do this, he tries to produce a quality, competitive, or entirely new product. To do so, he improves his technology, introduces innovation, that is, searches, finds, and uses in his own company. It costs its own expenses. At the same time, by spending considerable expense, they may not be well tolerated on the market. It cannot be reimbursed without paying enough volume. Any feature of the product may not be adequately considered. Therefore, any family entrepreneur should think and pay for every new job, innovation, and innovation. In the same way. there is a power that can lead a family entrepreneur to an innovative risk. This is a competitive force in the market. There is a strong competition in the market because of the large number of producers in the market. Each manufacturer tries to sell more products. Anyone who is tempted to lose consciousness can lose the competition if it is calm. Such a risk will be a constant link to any family businessman. That is why the family entrepreneur will become an innovative activity force. This is an innovative incentive.

A family entrepreneur should also have certain capabilities to engage in an innovative project. It should be the result of some fictional or scientifictechnical activity. A family entrepreneur can assign a research institution, purchase a license from an internal or external market, and conduct a patent research. In the event of a problem, scientists and researchers are working on this issue and try to find a solution. Therefore, a family entrepreneur should be able to bring their problems to research institutions. All these things require a family businessman to invest. You need to have money to make the innovation. In this case, a family entrepreneur should use the resources available to him, and use credit and loan instruments in his absence. Resource options vary from family to business. Attracting resources to crisis and depression is a big challenge. 


\begin{tabular}{|c|c|c|c|c|c|c|}
\hline \multirow{4}{*}{ Impact Factor: } & ISRA (India) & $=3.117$ & SIS (USA) & $=0.912$ & ICV (Poland) & $=6.630$ \\
\hline & ISI (Dubai, UAE & $=0.829$ & РИНЦ (Russia) & $=0.156$ & PIF (India) & $=1.940$ \\
\hline & GIF (Australia) & $=0.564$ & ESJI (KZ) & $=\mathbf{5 . 0 1 5}$ & IBI (India) & $=4.260$ \\
\hline & JIF & $=1.500$ & SJIF (Morocco) & $=5.667$ & OAJI (USA) & $=0.350$ \\
\hline
\end{tabular}

Any family businessman's skill, ability to risk, interest, and knowledge vary. They have different strategic thinking. In many cases, such attributes will depend on the age of the family businessman. Younger, younger family entrepreneurs are rewarded with innovation. In middle-aged family entrepreneurship, the interest in change is significantly reduced.

The third important factor in the innovation of family entrepreneurs is the limitations. Many entrepreneurs do not have enough resources to make big innovations, and they may not be able to raise funds from external sources. Therefore, family entrepreneurs can join some communities. This path can overcome such restrictions.

Time factor should also be taken into account. Costs such as innovation need more time to cover. The level of risk increases.

One of the most important factors of innovation risk is the continuity of scientific and technical activities. From time to time new types of products, new technologies can be created, and what has already been produced can quickly wipe out.

Hence, the innovative entrepreneurial potential of the family entrepreneur is not only infinite, but also endless. He will be limited in his own way. It is subject to various limitations. In such cases family businessmen are required to cooperate with the state.

There are three participants in the innovative partnership:

1. Family entrepreneur

2. Creative person

3. Civil society

As a creative person, anyone may be involved in the process of creating intellectual property. $\mathrm{He}$ can be a scientist, engineer, designer, technician, worker, manager, masters, postgraduate student. It is important for the teaching staff to teach the basics of scientific creativity in the school, institute and other educational institutions, continuing education, retraining and retraining.

\section{businesses \\ Increasing the productivity of family}

Moreover, it is important to improve the production system of family business and to increase production efficiency.

Descriptive description of the functioning of the production system is the functional structure of the system. When calculating the production costs and financial and economic outcomes of the production of items (workforce, labor weapon) in the production space by time and cost-based outcomes, the coefficient of production is used.

$$
\kappa \text { и.ч }=\frac{\left[\left(F K_{a . \phi}\right)+\left(E K_{a \grave{. \phi}}\right)\right]\left(P_{\text {фак }}+V\right) K_{n}}{(F+E)\left(P_{0}+V\right)}
$$

here:

F-- value of fixed assets;

E-- floating assets value;

V-- cocktail fund;

$\mathrm{K}_{a . \phi}, \mathrm{K}_{a u ̀ . \phi}, \mathrm{K}_{n}=$ the coefficient of using fixed assets, working capital and labor force;

Po, $\mathrm{P} \phi=$ ишлаб чиқариш фондларини норматив ва хақиқий даромадлилиги (рентабеллиги)

On the basis of analytical models, it is crucial to minimize the costs of business entities in the production system by reducing their cost. The following formula is used for this purpose:

$\mathrm{C}=\mathrm{S}+\sum_{1}^{m} S_{\varkappa}+\mathrm{Sp}+\sum_{1}^{n} S_{i . . \varkappa}+\mathrm{K}(\mathrm{Z} 3+\mathrm{Zc}+\mathrm{K} \kappa . . \mathrm{M})$

here:

$\mathrm{C}==\min ($ minimal) costs involved;

SM.X cocktail expenses;

$\mathrm{S}$ = maintenance costs;

$\mathrm{Sp}=$ planning and accounting costs;

Si.и.ж= expenses for a workplace;

$\mathrm{m}, \mathrm{n}=$ numbers of workplaces and workplaces;

$\mathrm{Z}_{3}, \mathrm{Zc}=$ unfinished construction;

Кк.м= additional capital resources;

Putting into practice all of the options discussed in the business entities will have a positive effect.

\section{Conclusions and Suggestions}

Family business is crucial in the economic liberalization of the economy, particularly in the provision of jobs for members of the community to actively participate in the production of a viable part. Therefore, it is necessary to strengthen the focus on the development of business activities by the state:

- further improvement of the level of government granting of economic benefits for family business activity development;

- to provide the most advanced technology for private enterprises, to reduce technological restrictions, simplify technical check-ups and control systems together with the provision of economic benefits for technical re-equipment;

- providing access to centralized resources, information databases, formation of social protection of entrepreneurs and consumers;

- Improvement of compulsory standards of foreign exchange earnings for entrepreneurs dealing with the processing of recycled products, development of interbank settlement system;

- effective use and development of leasing services in family business;

- Establishment of the Republican information system for studying demand and demand for products manufactured by enterprises;

In the end, we note that if the above-mentioned frauds are introduced in the development of entrepreneurial enterprises, the efficiency of 


\begin{tabular}{|c|c|c|c|c|c|c|}
\hline \multirow{4}{*}{ Impact Factor: } & ISRA (India) & $=3.117$ & SIS (USA) & $=0.912$ & ICV (Poland) & $=6.630$ \\
\hline & ISI (Dubai, UAE & $=0.829$ & РИНЦ (Russia) & $=0.156$ & PIF (India) & $=1.940$ \\
\hline & GIF (Australia) & $=0.564$ & ESJI (KZ) & $=\mathbf{5 . 0 1 5}$ & IBI (India) & $=4.260$ \\
\hline & JIF & $=1.500$ & SJIF (Morocco) & $=5.667$ & OAJI (USA) & $=0.350$ \\
\hline
\end{tabular}

entrepreneurship development will increase and the economy will rise.

\section{References:}

1. (2012). The Law of the Republic of Uzbekistan "On Family Entrepreneurship". Collection of the legislation of the Republic of Uzbekistan, No. 17, Art. 188.

2. Khodiev, B. Y., et al. (2003). Small business management. Tashkent: Teacher.

3. Hizrich, R., Piters, M. (1990). Predprinimatelstvo, ili kak zavest' sobstvennoe delo i dobit'sya uspekha. Moscow: Progress.

4. Gulomov S. S. (1998). Entrepreneurship and small business. T.: University.

5. Abdullaev, Y., Karimov, F. (2000). Fundamentals of small business and entrepreneurship. T.: Mehnat.

6. Berkinov, B. B., \& Akhmedov, U. Q. (2013). Households' development and family income growth prospects. (p.144). Tashkent: Science and Technology.

7. Tursunov, B. (2017). Ways of increasing the efficiency of usage the production capacity of textile enterprises. Byulleten' nauki i praktiki, (8), 232-242.

8. Tursunov, B. (2017). Features of the method of calculation of production capacities of the textile enterprises. Byulleten' nauki i praktiki, (10), 213-222

9. Kachaner, Stalk, Bloch (2012, November). "What can you learn from Family Business? Harvard Business Review."

10. Carlock, R. S., Manfred, K. V., \& FlorencyTreacy, E. (2007) Family Business. International Encyclopedia of Organization Studies.

11. Shodieva, G. M. (2008). Problems of organizational and economic factors and service development in the improvement of family welfare. Dissertation for the degree of Doctor of Economics. Samarkand. 